\title{
Classifying Soybean Cultivars Using an Univariate and Multivariate Approach
}

\author{
João Paulo Santos Carvalho ${ }^{1}$, Adriano Teodoro Bruzi ${ }^{1}$, Karina Barroso Silva ${ }^{1}$, Igor Oliveri Soares ${ }^{2}$, \\ Mariane Cristina Bianchi ${ }^{1} \&$ Nelson Junior Dias Vilela ${ }^{1}$ \\ ${ }^{1}$ Plant Sciences Department, Federal University of Lavras, Lavras, MG, Brazil \\ ${ }^{2}$ Research-Timac Agro, Brazil \\ Correspondence: Karina Barroso Silva, Plant Sciences Department, Federal University of Lavras, Campus \\ Universitário, Caixa Postal 3037, Lavras, Minas Gerais, Brazil. Tel: 55-(35)-3829-5119. E-mail: \\ karina.rbarroso@gmail.com
}

Received: September 4, 2019

Accepted: September 21, 2020

Online Published: October 15, 2020

doi:10.5539/jas.v12n11p190

URL: https://doi.org/10.5539/jas.v12n11p190

\begin{abstract}
Selection indices are good for classification because they consider several evaluated traits simultaneously to identify superior cultivars with a combination of the traits of interest. Adaptability/stability methods enable determining contributions to the genotype-by-environment $(\mathrm{G} \times \mathrm{E})$ interaction and the risk associated with each cultivar. This study used a univariate and multivariate strategy to identify commercial soybean cultivars that presented both precocity and good productive performance and studied the $\mathrm{G} \times \mathrm{E}$ interaction considering all cultivars both simultaneously and by maturation groups. The experiments were conducted in the agricultural years 2014/15 and 2015/16 in seven distinct environments in southern Minas Gerais State, Brazil, considering a combination of locations and seasons. A randomized complete block design was used, and the treatments included 35 commercial soybean cultivars. In the univariate analysis, were evaluate several traits. Selection indices were calculated considering yield, harvest index, plant height, first pod insertion height and absolute maturation. The selection strategy efficiencies were quantified using the coincidence index. Each cultivar's contribution to the $\mathrm{G} \times$ $\mathrm{E}$ interaction and associated risk were determined using the ecovalence and confidence index methods, respectively. The results showed that the NS 7000 IPRO and NS 7209 IPRO cultivars were the most productive. The NS 7000 IPRO cultivar, although obtaining a good yield, contributed greatly to the $\mathrm{G} \times \mathrm{E}$ interaction when considering the maturation groups. The low coincidence in ranking the strategies indicates that more than one agronomic trait should be used to classify the superior cultivars.
\end{abstract}

Keywords: adaptability/stability, coincidence index, genotype-by-environment interaction, Glycine max (L.) Merr, selection index

\section{Introduction}

The main objective of breeding programs is to obtain cultivars that surpass pre-existing cultivars. Having additional advantages is only possible if the new cultivar combines a set of phenotypes favorable for the traits of interest, such as high yield, resistance or tolerance to pests and diseases, efficient nutrient and water use and good architecture (Ramalho et al., 2012).

Breeders measure several traits to identify cultivars for specific regions. A question that arises is whether coincidence exists between the selected cultivars classifications considering only the attribute of greater relevance (grain yield) and the ranking based on index selection considering more than one trait. Reports in the literature describe using index selection in soybeans (Silva et al., 2016; Soares et al., 2015), however, these studies revealed no coincidence in the classification considering the different strategies.

The genotype-by-environment $(\mathrm{G} \times \mathrm{E})$ interaction is the main complicating factor in recommending cultivars. Thus, adopting strategies to identify more stable cultivars confers reliability to breeders work. Previous research has been conducted on using this strategy in soybeans in Minas Gerais State, Brazil (Silva et al., 2015); however, no reports exist on stability analyses considering different maturation groups. 
This study used a univariate and multivariate strategy to identify commercial soybean cultivars that combine precocity and high performance and are adapted to the southern region of Minas Gerais and studied the $\mathrm{G} \times \mathrm{E}$ interaction considering all cultivars both simultaneously and by maturation group.

\section{Materials and Methods}

The experiments were conducted in two agricultural years, 2014/2015 and 2015/2016, in different environments of Minas Gerais State, Brazil. In the 2014/15 season, experiments were conducted in the municipality of Lavras at the Center for Scientific and Technological Development in Agriculture, Muquém Farm, at $21^{\circ} 14^{\prime} \mathrm{S}, 45^{\circ} 00^{\prime} \mathrm{W}$ and an altitude of $918 \mathrm{~m}$; the municipality of Itutinga, Milanez Farm, at $21^{\circ} 17^{\prime} 52^{\prime \prime} \mathrm{S}, 44^{\circ} 39^{\prime} 28^{\prime \prime} \mathrm{W}$ and an altitude of 969 $\mathrm{m}$; and in the municipality of Ijaci at the Center for Scientific and Technological Development in Agriculture, Palmital Farm, at $21^{\circ} 09^{\prime} \mathrm{S}, 44^{\circ} 54^{\prime} \mathrm{W}$ and an altitude of $920 \mathrm{~m}$. In the $2015 / 16$ season, in addition to the previously described municipalities (Lavras, Ijaci and Itutinga), experiments were also conducted in the municipality of Nazareno at Grupo G7 Farm, at 21 ${ }^{\circ} 12^{\prime} 59^{\prime \prime} \mathrm{S}, 44^{\circ} 36^{\prime} 41^{\prime \prime}$ W and an altitude of $935 \mathrm{~m}$.

Thirty-five soybean cultivars were used, including 23 RR (Roundup Ready) cultivars and 12 cultivars with the IPRO technology (Intacta Bt RR2) (Table 1).

Table 1. Soybean genotypes and corresponding maturation group (MG) and growth habit (GH) information

\begin{tabular}{lll|lll}
\hline Cultivars & MG & GH & Cultivars & MG & GH \\
\hline FPS Iguaçu & 5.0 & $\mathrm{U}^{1}$ & 5D 690 RR & 6.9 & $\mathrm{U}$ \\
NS 5106 IPRO & 5.1 & $\mathrm{U}$ & NS 6909 IPRO & 6.9 & $\mathrm{U}$ \\
NS 5151 IPRO & 5.1 & $\mathrm{U}$ & NS 7000 IPRO & 7.0 & $\mathrm{U}$ \\
95R51 & 5.5 & $\mathrm{U}$ & CD 238 RR & 7.1 & $\mathrm{D}$ \\
CD 250 RR & 5.5 & $\mathrm{U}$ & M 7110 IPRO & 7.1 & $\mathrm{U}$ \\
FPS Paranapanema RR & 5.6 & $\mathrm{PD}^{2}$ & TMG 716 RR & 7.1 & $\mathrm{U}$ \\
FPS Solimões RR & 5.7 & $\mathrm{U}$ & 97R21 & 7.2 & $\mathrm{U}$ \\
FPS Atlanta & 5.8 & $\mathrm{U}$ & NS 7209 IPRO & 7.2 & $\mathrm{U}$ \\
RK 5813 RR & 5.8 & $\mathrm{U}$ & CG 68 RR & 7.3 & $\mathrm{U}$ \\
FPS Júpiter RR & 5.9 & $\mathrm{U}$ & NS 7300 IPRO & 7.3 & $\mathrm{U}$ \\
NS 5909 IPRO & 5.9 & $\mathrm{U}$ & NS 7338 IPRO & 7.3 & $\mathrm{U}$ \\
NS 5959 IPRO & 5.9 & $\mathrm{U}$ & CG 67 RR & 7.4 & PD \\
5D 615 RR & 6.1 & $\mathrm{U}$ & CG 7464 RR & 7.4 & PD \\
FPS Urano RR & 6.2 & $\mathrm{D}^{3}$ & CG 7665 RR & 7.6 & PD \\
FPS Netuno RR & 6.3 & $\mathrm{U}$ & $5 \mathrm{G} \mathrm{770} \mathrm{RR}$ & 7.7 & $\mathrm{U}$ \\
FPS Solar IPRO & 6.3 & $\mathrm{U}$ & CG 8166 RR & 7.7 & $\mathrm{U}$ \\
FPS Antares RR & 6.8 & $\mathrm{U}$ & $5 \mathrm{G} \mathrm{830} \mathrm{RR}$ & 8.3 & $\mathrm{D}$ \\
RK 6813 RR & 6.8 & $\mathrm{U}$ & - & - & - \\
\hline
\end{tabular}

Note. ${ }^{1}$ Undetermined; ${ }^{2}$ Partially determined; ${ }^{3}$ Determined.

The experiments were conducted using a randomized block design with three replicates. The experimental plots consisted of two $5 \mathrm{~m}$ long rows, with $0.50 \mathrm{~m}$ spacing between rows. Seeding was performed manually in the first half of November in all production environments. Fertilization consisted of $350 \mathrm{~kg}$ ha ${ }^{-1}$ of the $\mathrm{N}_{-} \mathrm{P}_{2} \mathrm{O}_{5}-\mathrm{K}_{2} \mathrm{O}$ (02-30-20) formulation applied in the planting groove. The planting groove was inoculated with the bacterium, Bradyrhizobium japonicum, after sowing at $18 \mathrm{~mL}$ commercial product (cp) $\mathrm{kg}^{-1}$ of seed (SEMIA 5079 and 5080 strains) containing $10.8 \times 10^{6}$ colony-forming units $(\mathrm{CFU}) /$ seed of the Nitragin Cell Tech HC $\left(\right.$ inoculant $\left(3 \times 10^{9}\right.$ $\mathrm{CFU} / \mathrm{mL}$ ), using a motorized backpack bar sprayer with a bar fitted with four XR 11002 spray nozzles, at a spray volume equivalent to $150 \mathrm{~L} \mathrm{ha}^{-1}$.

Pest control was performed based on crop need using neonicotinoid, pyrethroid and chlorpyrifos insecticides. Postemergence weed control was performed using $2 \mathrm{~L} \mathrm{ha}^{-1}$ glyphosate.

\subsection{The Following Traits Were Evaluated}

- Absolute maturation: $90 \%$ of the plants in the plot were in stage R8 (absolute maturation) per the scale (Fehr \& Caviness, 1977);

- First pod insertion height: distance from the plant neck to the node with initiation of the first pod, in centimeters, of 5 randomly sampled plants; 
- Plant height: distance from the plant neck to the end of the main stem, in centimeters, measured in 5 random sampled plants;

- Lodging index: evaluated per Bernard et al. (1965) with the following scores: $1=$ almost all plants erect; $2=$ all plants leaning slightly or a few plants down; $3=$ all plants leaning moderately, or $25 \%$ to $50 \%$ of the plants down; $4=$ all plants leaning considerably, or $50 \%$ to $80 \%$ of the plants down; and $5=$ more than $80 \%$ of the plants down;

- Grain yield: value in bags.ha ${ }^{-1}$ after correction to $13 \%$ moisture;

- Weight of 100 grains: this determination followed the recommendations of Brasil (2009), using eight replicates of 100 seeds from each lot's pure seed portion, where each sample was individually weighed, and the results were expressed in grams (g);

- Harvest index: ratio of grain weight to total plant dry weight. Five plants were collected in each useful plot and were weighed before thrashing. The total seed weight was divided by the plant weight, giving the harvest index;

- Number of pods, grains and grains per pod: Were collected five randomized plants and counted the number of pods and grains. The number of grains per pod was calculated dividing the number of grains by the number of pods.

The analyses of variance were performed using R Core Team software (2016). The means obtained were grouped by the Scott-Knott test (1974) at 5\% probability. The experimental precision was measured by estimating the coefficient of variation (CV) and the selection accuracy (Resende \& Duarte, 2007).

Once the mean productivity measures were calculated, cultivar stability was evaluated per the method of Wricke (1965). Each cultivars ecovalence was estimated by dividing the sum of squares of the cultivar $\times$ environment interaction. The confidence index (Ii) proposed by Annicchiarico (1992) was also estimated.

Stability was estimated considering all cultivars simultaneously and separated by maturation group (groups I: 5.0 to 5.9; II: 6.0 to 7.0; and III: 7.1 to 8.3 ). The mean square of the interaction was divided into simple and complex parts using the estimator presented by Cruz and Castoldi (1991).

In the index of the sum of the standardized variables, the observations for yield, harvest index, plant height, first pod insertion height and absolute maturation were standardized to enable direct comparisons. As the $Z$ variable assumes both negative and positive values, a constant was added to make the values positive (Mendes et al., 2009).

Use of this five-trait simultaneous index selection assumes that greater $\mathrm{Z}$ values yield better selection. However, for the lodging trait, the lower the trait's value, the better the cultivar. Thus, to make the effect of five traits follow the same direction, the values of the $\mathrm{Z}$ index for lodging were multiplied by -1 . After standardizing, each plants $\mathrm{Z}$ value was summed.

The sum of ranks (SR) of the lines was calculated by assigning ranks to classify the cultivars by their mean performance in each environment (Mulamba \& Mock, 1978), considering grain yield, harvest index, plant height, first pod insertion height and absolute maturation. Thus, the environments most productive cultivar was ranked "one", while the least productive cultivar received the traits lowest possible rank. Each cultivars rank for a given trait was added using the expression:

$$
\mathrm{SR}_{\mathrm{ik}}=\mathrm{P}_{\mathrm{YIE}}+\mathrm{P}_{\mathrm{HI}}+\mathrm{P}_{\mathrm{HGT}}+\mathrm{P}_{\mathrm{INS}}+\mathrm{P}_{\mathrm{MA}}
$$

where,

$S P R_{i k}$ : sum of ranks for cultivar $i$ in environment $k ; P_{Y I E}$ : grain yield rank; $P_{H I}$ : harvest index rank; $P_{H G T}$ : plant height rank; $P_{I N S}$ : first pod insertion height rank; $P_{M A}$ : absolute maturation rank.

Spearman's correlation was calculated for the productivity ranks in the univariate analysis, the sum of the standardized variables ( $\mathrm{Z}$ index) and the sum of ranks (SR).

Using the statistical software Genes (Cruz, 2013), the coincidence index proposed by Hamblin and Zimmermann (1986) was calculated with selection intensities of $5 \%, 10 \%, 15 \%, 20 \%, 25 \%$ and $30 \%$ to test the coincidence of the superior cultivars comparing the three methods, using the equation:

$$
\mathrm{IC}=\frac{\mathrm{E}-\mathrm{C}}{\mathrm{M}-\mathrm{C}} \times 100
$$

where,

C: number of selected superior cultivars; E: number of selected superior cultivars common to the different environments; M: number of selected superior cultivars in one of the environments or traits. 


\section{Results}

All evaluated traits differed significantly for both the cultivar and environmental factors. The differences in cultivar performance can be explained mainly by the genetic background, i.e., differences due to absolute maturation, growth habits, and pathogen resistance (Table 2).

Table 2. Summary of the joint analysis of variance for all traits evaluated, considering the seven environments

\begin{tabular}{|c|c|c|c|c|c|c|c|c|c|c|c|c|}
\hline \multirow{2}{*}{ SV } & \multirow{2}{*}{$\mathrm{DF}$} & \multicolumn{11}{|c|}{ MS } \\
\hline & & $\mathrm{HI}$ & NP & NG & NGP & YIE & W100 & DIC & LODG & HGT & INS & MA \\
\hline Cultivars (G) & 34 & $0.027^{*}$ & $1452.200 *$ & $4302.200^{*}$ & $0.293 *$ & $1098.100^{*}$ & 79.694* & $173.350 *$ & $7.093^{*}$ & $3330.000 *$ & $187.650^{*}$ & $564.700 *$ \\
\hline Environments (E) & 6 & $0.032 *$ & $5747.300 *$ & $13865.200 *$ & $3.292 *$ & $10862.300^{*}$ & $177.024^{*}$ & $1979.110^{*}$ & $27.427 *$ & $36753.000^{*}$ & $1324.410^{*}$ & $4283.500 *$ \\
\hline repetition: $\mathrm{E}$ & 14 & 0.006 & 141.700 & 899.100 & 0.275 & 158.400 & 3.477 & 43.520 & 2.173 & 232.000 & 10.830 & 47.800 \\
\hline $\mathrm{G} \times \mathrm{E}$ & 204 & $0.004 *$ & $231.400^{*}$ & $930.800^{*}$ & $0.114 *$ & $251.900 *$ & $5.285^{*}$ & $55.280^{*}$ & $1.230^{*}$ & $93.000^{*}$ & $11.970^{*}$ & $45.100^{*}$ \\
\hline G $\times$ E Simple $(\%)$ & & $(6.437)$ & (16.864) & (14.538) & $(1.568)$ & $(4.641)$ & (13.287) & $(3.072)$ & - & $(26.66)$ & $(8.691)$ & (8.978) \\
\hline $\mathrm{G} \times$ E Complex $(\%)$ & & (93.562) & (83.135) & $(85.461)$ & $(98.431)$ & $(95.358)$ & $(86.712)$ & $(96.927)$ & - & (73.330) & (91.308) & (91.021) \\
\hline Error & $\begin{array}{l}468\left(466^{1}\right)\left(464^{2}\right) \\
\left(472^{3}\right)\left(462^{4}\right)\end{array}$ & $0.004^{1}$ & 122.900 & 475.500 & 0.066 & 66.500 & 1.5450 & $16.210^{2}$ & $0.429^{3}$ & 45.000 & 5.120 & $12.200^{4}$ \\
\hline Fc (Cultivars) & & 6.542 & 11.815 & 9.047 & 4.400 & 16.524 & 51.570 & 10.696 & 16.498 & 74.097 & 36.679 & 46.4700 \\
\hline CV (\%) & & 12.724 & 27.400 & 28.100 & 13.367 & 15.300 & 6.440 & 15.500 & 41.500 & 8.300 & 14.200 & 2.800 \\
\hline Accuracy (\%) & & 92.040 & 95.670 & 94.310 & 87.910 & 96.930 & 99.030 & 95.210 & 96.920 & 99.320 & 98.630 & 98.920 \\
\hline General average & & 0.51 & 40.49 & 77.56 & 1.93 & 53.18 & 19.30 & 25.91 & 1.58 & 80.58 & 15.97 & 122.53 \\
\hline
\end{tabular}

Note. SV: source of variation, DF: degrees of freedom; Fc: calculated F; CV: coefficient of variation; HI: harvest index; NP: number of pods; NG: number of grains; NGP: number of grains per pod; YIE: grain yield; W100: weight of 100 grains; DIC: daily increment; LODG: lodging; HGT: height; INS: first pod insertion height; MA: absolute maturation; MS: mean square. ${ }^{1},{ }^{2},{ }^{3},{ }^{4}$ correspond to the degrees of freedom of error. *Significant at $95 \%$ confidence by the F test.

The Table 3 presents the means for all traits among the 35 cultivars, and all traits varied. For mean grain yield, the NS 7000 IPRO cultivar obtained the best result, yielding $64.88 \mathrm{bags} \mathrm{ha}^{-1}$. This was $18.12 \%$ higher than the national mean of 52.93 bags $^{-1} a^{-1}$. The FPS Iguaçu cultivar performed the worst, with a mean of $34.90 \mathrm{bags} \mathrm{ha}^{-1}$. The absolute maturation trait varied by 18 days among the cultivars. The SPF Iguaçu cultivar was the most precocious at 113 days, while the CG 8166 RR, GC 7665 RR and 5G 770 RR cultivars were the least precocious at 131 days. 
Table 3. Means of the joint analysis for the traits evaluated in the seven environments in two agricultural years $(2014 / 15$ and 2015/16)

\begin{tabular}{|c|c|c|c|c|c|c|c|c|c|c|c|}
\hline Cultivars & $\mathrm{HI}$ & NP & NG & NGP & YIE & W100 & HGT & INS & LODG & MA & DIC \\
\hline NS7000 IPRO & $52 \mathrm{a}$ & $61 \mathrm{c}$ & $.77 \mathrm{c}$ & $94 \mathrm{c}$ & $1.88 \mathrm{a}$ & $2.75 \mathrm{~b}$ & $8.72 \mathrm{~d}$ & $8.83 \mathrm{~b}$ & $1.33 \mathrm{c}$ & $24 \mathrm{c}$ & $30.95 \mathrm{a}$ \\
\hline RO & $52 \mathrm{a}$ & $4.77 \mathrm{~d}$ & $.02 \mathrm{~d}$ & $92 \mathrm{c}$ & $63.86 \mathrm{a}$ & $23.88 \mathrm{a}$ & $82.62 \mathrm{e}$ & $19.43 \mathrm{~b}$ & $2.04 \mathrm{~b}$ & $125 \mathrm{c}$ & $30.31 \mathrm{a}$ \\
\hline NS 7300 IPRO & $54 \mathrm{a}$ & $36.85 \mathrm{c}$ & & $4 \mathrm{c}$ & & $21.01 \mathrm{c}$ & $81.44 \mathrm{e}$ & $56 \mathrm{c}$ & $23 \mathrm{~b}$ & $27 \mathrm{c}$ & $.12 \mathrm{a}$ \\
\hline CG 68 RR & $50 \mathrm{a}$ & $8.07 \mathrm{c}$ & $4.52 \mathrm{c}$ & $.96 \mathrm{c}$ & $.49 \mathrm{a}$ & $19.36 \mathrm{~d}$ & $81.82 \mathrm{e}$ & $8.38 \mathrm{c}$ & $1.09 \mathrm{~d}$ & $125 \mathrm{c}$ & $29.48 \mathrm{a}$ \\
\hline $\mathrm{CG}^{\prime}$ & $52 \mathrm{a}$ & $54.52 \mathrm{a}$ & $108.02 \mathrm{a}$ & $1.99 \mathrm{c}$ & $61.10 \mathrm{a}$ & $17.50 \mathrm{~g}$ & $87.45 \mathrm{~d}$ & $17.46 \mathrm{c}$ & $1.66 \mathrm{c}$ & $128 \mathrm{~b}$ & $28.05 \mathrm{~b}$ \\
\hline NS 7338 IPRO & $0.52 \mathrm{a}$ & & & $1.93 \mathrm{c}$ & & $20.43 \mathrm{c}$ & $82.61 \mathrm{e}$ & $77 \mathrm{~b}$ & $2.10 \mathrm{~b}$ & $128 \mathrm{~b}$ & $28.16 \mathrm{~b}$ \\
\hline CD $238 \mathrm{RR}$ & $0.41 \mathrm{c}$ & $50.45 \mathrm{~b}$ & $94.43 \mathrm{a}$ & $1.77 \mathrm{~d}$ & $59.29 \mathrm{a}$ & $19.61 \mathrm{~d}$ & $94.93 \mathrm{~b}$ & $19.31 \mathrm{~b}$ & $1.71 \mathrm{c}$ & $128 \mathrm{~b}$ & $27.54 \mathrm{~b}$ \\
\hline FPS & $50 \mathrm{a}$ & $41.08 \mathrm{c}$ & & $1.94 \mathrm{c}$ & $59.28 \mathrm{a}$ & $19.43 \mathrm{~d}$ & & $15.80 \mathrm{e}$ & $1.47 \mathrm{c}$ & $124 \mathrm{c}$ & $28.62 \mathrm{a}$ \\
\hline CG 8166 RR & $0.46 \mathrm{~b}$ & $54.28 \mathrm{a}$ & $102.37 \mathrm{a}$ & $1.86 \mathrm{~d}$ & & $18.05 \mathrm{f}$ & & $2 \mathrm{a}$ & $2.80 \mathrm{a}$ & $131 \mathrm{a}$ & $26.60 \mathrm{~b}$ \\
\hline CG 7665 RR & $0.45 \mathrm{~b}$ & $51.06 \mathrm{~b}$ & $91.84 \mathrm{~b}$ & $1.78 \mathrm{~d}$ & $58.50 \mathrm{a}$ & $19.61 \mathrm{~d}$ & $97.99 \mathrm{~b}$ & $21.46 \mathrm{a}$ & $2.47 \mathrm{a}$ & $131 \mathrm{a}$ & $26.64 \mathrm{~b}$ \\
\hline & $.51 \mathrm{a}$ & $38.08 \mathrm{c}$ & & $1.97 \mathrm{c}$ & $58.23 \mathrm{a}$ & $18.55 \mathrm{e}$ & & $7 \mathrm{~d}$ & $2.00 \mathrm{~b}$ & $122 \mathrm{~d}$ & $28.42 \mathrm{a}$ \\
\hline RK 68 & & & & & & & & & & $123 \mathrm{~d}$ & $.02 \mathrm{~b}$ \\
\hline 97R21 & $0.49 \mathrm{a}$ & $47.44 \mathrm{~b}$ & $83.10 \mathrm{~b}$ & $1.74 \mathrm{~d}$ & $56.64 \mathrm{~b}$ & $19.73 \mathrm{~d}$ & $91.87 \mathrm{c}$ & $19.95 \mathrm{~b}$ & $2.28 \mathrm{~b}$ & $125 \mathrm{c}$ & $27.05 \mathrm{~b}$ \\
\hline & $0.53 \mathrm{a}$ & $41.39 \mathrm{c}$ & & $2.11 \mathrm{~b}$ & $56.13 \mathrm{~b}$ & $20.77 \mathrm{c}$ & $80.36 \mathrm{e}$ & & $1.40 \mathrm{c}$ & $122 \mathrm{~d}$ & $27.13 \mathrm{~b}$ \\
\hline & & & & & & & & & & & \\
\hline FPS S & $0.52 \mathrm{a}$ & $36.56 \mathrm{c}$ & $75.25 \mathrm{c}$ & $2.03 \mathrm{c}$ & $54.97 \mathrm{~b}$ & $19.08 \mathrm{e}$ & $84.79 \mathrm{~d}$ & $16.20 \mathrm{~d}$ & $1.19 \mathrm{~d}$ & $122 \mathrm{~d}$ & $26.85 \mathrm{~b}$ \\
\hline RK 5 & $0.53 \mathrm{a}$ & $42.56 \mathrm{c}$ & $82.58 \mathrm{~b}$ & $1.95 \mathrm{c}$ & $54.25 \mathrm{~b}$ & $16.65 \mathrm{~h}$ & $72.26 \mathrm{f}$ & $12.44 \mathrm{~g}$ & $1.30 \mathrm{c}$ & $120 \mathrm{e}$ & $27.94 \mathrm{~b}$ \\
\hline CG 6 & & & & & & & & & & $126 \mathrm{c}$ & $33 \mathrm{~b}$ \\
\hline $5 \mathrm{G} 7$ & $0.43 \mathrm{~b}$ & & & $1.82 \mathrm{~d}$ & & & $109.41 \mathrm{a}$ & & $2.76 \mathrm{a}$ & $131 \mathrm{a}$ & $24.53 \mathrm{c}$ \\
\hline NS 5 & $0.54 \mathrm{a}$ & $31.01 \mathrm{~d}$ & $62.81 \mathrm{~d}$ & $2.01 \mathrm{c}$ & $53.74 \mathrm{~b}$ & $20.87 \mathrm{c}$ & $74.55 \mathrm{f}$ & $14.05 \mathrm{f}$ & $1.00 \mathrm{~d}$ & $118 \mathrm{f}$ & $27.39 \mathrm{~b}$ \\
\hline FPS A & & & & $2.06 \mathrm{~b}$ & & $20.13 \mathrm{~d}$ & & $13.94 \mathrm{f}$ & $1.00 \mathrm{~d}$ & $119 \mathrm{f}$ & $26.77 \mathrm{~b}$ \\
\hline & & & $110.48 \mathrm{a}$ & & & & & & & $129 \mathrm{~b}$ & $24.16 \mathrm{c}$ \\
\hline NS 5 & $0.51 \mathrm{a}$ & $36.44 \mathrm{c}$ & $73.43 \mathrm{c}$ & $2.01 \mathrm{c}$ & $52.68 \mathrm{~b}$ & $20.88 \mathrm{c}$ & $74.36 \mathrm{f}$ & $13.76 \mathrm{f}$ & $1.04 \mathrm{~d}$ & $118 \mathrm{f}$ & $26.72 \mathrm{~b}$ \\
\hline NS 515 & & & & $2.00 \mathrm{c}$ & & & $62.55 \mathrm{~g}$ & $12.34 \mathrm{~g}$ & $1.00 \mathrm{~d}$ & $116 \mathrm{~g}$ & $26.29 \mathrm{~b}$ \\
\hline 5D $690 \mathrm{RR}$ & & & & $1.60 \mathrm{e}$ & & & $79.11 \mathrm{e}$ & $16.96 \mathrm{~d}$ & $1.47 \mathrm{c}$ & $128 \mathrm{~b}$ & $22.76 \mathrm{c}$ \\
\hline FPS Júpiter R & $0.53 \mathrm{a}$ & $39.14 \mathrm{c}$ & $73.73 \mathrm{c}$ & $1.92 \mathrm{c}$ & $48.35 \mathrm{c}$ & $18.53 \mathrm{e}$ & $71.64 \mathrm{f}$ & $14.95 \mathrm{e}$ & $1.04 \mathrm{~d}$ & $121 \mathrm{e}$ & $23.97 \mathrm{c}$ \\
\hline 5D $615 \mathrm{RR}$ & $0.49 \mathrm{a}$ & $32.67 \mathrm{~d}$ & $62.77 \mathrm{~d}$ & $1.95 \mathrm{c}$ & $48.32 \mathrm{c}$ & $18.97 \mathrm{e}$ & $78.15 \mathrm{e}$ & $14.64 \mathrm{e}$ & $1.09 \mathrm{~d}$ & $115 \mathrm{~g}$ & $25.13 \mathrm{c}$ \\
\hline FPS Urano RR & & & & $1.87 \mathrm{~d}$ & & & & & $1.00 \mathrm{~d}$ & $124 \mathrm{c}$ & $22.01 \mathrm{c}$ \\
\hline TMG 716 RR & $0.47 \mathrm{~b}$ & $37.44 \mathrm{c}$ & $66.52 \mathrm{~d}$ & $1.80 \mathrm{~d}$ & $45.80 \mathrm{~d}$ & $17.82 \mathrm{f}$ & $91.00 \mathrm{c}$ & $18.21 \mathrm{c}$ & $1.52 \mathrm{c}$ & $120 \mathrm{e}$ & $22.73 \mathrm{c}$ \\
\hline NS 5106 IPRO & $0.57 \mathrm{a}$ & $29.36 \mathrm{~d}$ & $55.53 \mathrm{~d}$ & $1.88 \mathrm{~d}$ & $45.21 \mathrm{~d}$ & $21.23 \mathrm{c}$ & $56.68 \mathrm{~h}$ & $10.88 \mathrm{~h}$ & $1.00 \mathrm{~d}$ & $118 \mathrm{f}$ & $22.91 \mathrm{c}$ \\
\hline FPS Solimões RR & $0.52 \mathrm{a}$ & & & $1.85 \mathrm{~d}$ & & $16.46 \mathrm{~h}$ & & & $1.28 \mathrm{c}$ & $119 \mathrm{e}$ & $22.60 \mathrm{c}$ \\
\hline FPS Paranapanema RR & $0.54 \mathrm{a}$ & $38.87 \mathrm{c}$ & $74.11 \mathrm{c}$ & $1.85 \mathrm{~d}$ & $44.24 \mathrm{~d}$ & $17.49 \mathrm{~g}$ & $60.19 \mathrm{~g}$ & $10.87 \mathrm{~h}$ & $1.00 \mathrm{~d}$ & $118 \mathrm{f}$ & $22.62 \mathrm{c}$ \\
\hline 95R51 & $0.54 \mathrm{a}$ & $35.30 \mathrm{c}$ & $71.77 \mathrm{c}$ & $1.92 \mathrm{c}$ & $42.96 \mathrm{~d}$ & $18.35 \mathrm{f}$ & $63.08 \mathrm{~g}$ & $11.16 \mathrm{~h}$ & $1.09 \mathrm{~d}$ & $114 \mathrm{~h}$ & $22.84 \mathrm{c}$ \\
\hline CD 250 & $0.51 \mathrm{a}$ & $33.94 \mathrm{~d}$ & $74.72 \mathrm{c}$ & $2.26 \mathrm{a}$ & $37.64 \mathrm{e}$ & $16.63 \mathrm{~h}$ & $82.04 \mathrm{e}$ & $15.15 \mathrm{e}$ & $1.85 \mathrm{~b}$ & $114 \mathrm{~h}$ & $20.02 \mathrm{~d}$ \\
\hline FPS Iguaçu RR & $0.51 \mathrm{a}$ & $37.00 \mathrm{c}$ & $66.74 \mathrm{~d}$ & $1.87 \mathrm{~d}$ & $34.90 \mathrm{e}$ & $22.41 \mathrm{~b}$ & $78.60 \mathrm{e}$ & $13.30 \mathrm{f}$ & $1.42 \mathrm{c}$ & $113 \mathrm{~h}$ & $18.72 \mathrm{~d}$ \\
\hline
\end{tabular}

Note. Means followed by the same letter in the columns belong to the same group by the Scott-Knott test at $95 \%$ reliability. HI: harvest index; NP: number of pods; NG: number of grains; NGP: number of grains per pod; YIE: yield (bags ha $\left.{ }^{-1}\right)$; W100: weight of 100 grains; DIC: daily increment $\left(\mathrm{kg} \mathrm{ha}^{-1}\right.$ days $\left.^{-1}\right)$; LODG: lodging $(\mathrm{cm})$; HGT: height $(\mathrm{cm})$; INS: first pod insertion height $(\mathrm{cm})$; MA: absolute maturation (days).

When working with various traits, multivariate analysis is an alternative for identifying the best cultivars. Two selection indices were used in this study. The Table 4 presents the cultivar rankings based on the univariate analysis (grain yield), the sum of ranks index (SR) and the sum of standardized variables index ( $\mathrm{Z}$ index). The NS 7000 IPRO and NS 7209 IPRO cultivars stood out, reaching the first and second ranks, respectively. 
Table 4. Cultivar rankings based on univariate analysis, sum of ranks index (SR) and sum of standardized variables index ( $\mathrm{Z}$ index)

\begin{tabular}{|c|c|c|c|}
\hline Cultivars & Univariate & SR & $\mathrm{Z}$ index \\
\hline NS7000 IPRO & 1 & 1 & 1 \\
\hline NS 7209 IPRO & 2 & 2 & 2 \\
\hline NS 7300 IPRO & 3 & 6 & 6 \\
\hline CG 68 RR & 4 & 7 & 5 \\
\hline CG 7464 RR & 5 & 8 & 9 \\
\hline NS 7338 IPRO & 6 & 5 & 10 \\
\hline CD 238 RR & 7 & 7 & 22 \\
\hline FPS Antares RR & 8 & 9 & 11 \\
\hline CG 8166 RR & 9 & 5 & 12 \\
\hline CG 7665 RR & 10 & 4 & 16 \\
\hline FPS Netuno RR & 11 & 5 & 4 \\
\hline RK 6813 RR & 12 & 8 & 7 \\
\hline 97R21 & 13 & 3 & 3 \\
\hline M7110 IPRO & 14 & 12 & 14 \\
\hline NS 6909 IPRO & 15 & 19 & 18 \\
\hline FPS Solar RR & 16 & 10 & 13 \\
\hline RK 5813 RR & 17 & 19 & 26 \\
\hline CG 67 RR & 18 & 11 & 15 \\
\hline 5G $770 \mathrm{RR}$ & 19 & 16 & 24 \\
\hline NS 5959 IPRO & 20 & 13 & 8 \\
\hline FPS Atlanta IPRO & 21 & 18 & 23 \\
\hline 5G $830 \mathrm{RR}$ & 22 & 15 & 30 \\
\hline NS 5909 IPRO & 23 & 19 & 21 \\
\hline NS 5151 IPRO & 24 & 21 & 25 \\
\hline 5D $690 \mathrm{RR}$ & 25 & 22 & 33 \\
\hline FPS Júpiter RR & 26 & 21 & 27 \\
\hline 5D $615 \mathrm{RR}$ & 27 & 17 & 17 \\
\hline FPS Urano RR & 28 & 27 & 35 \\
\hline TMG 716 RR & 29 & 11 & 19 \\
\hline NS 5106 IPRO & 30 & 24 & 34 \\
\hline FPS Solimões RR & 31 & 25 & 31 \\
\hline FPS Paranapanema RR & 32 & 26 & 32 \\
\hline 95R51 & 33 & 23 & 29 \\
\hline CD 250 & 34 & 14 & 20 \\
\hline FPS Iguaçu RR & 35 & 20 & 28 \\
\hline
\end{tabular}

The Spearman correlation obtained was significant and positive for all comparisons; the value for univariate analysis $\times$ SR was 0.8436 ; the value for univariate analysis $\times \mathrm{Z}$ index was 0.7988 , and the value for the comparison between $\mathrm{SR} \times \mathrm{Z}$ index was 0.8921 , indicating that although the index selection considers more traits, yield remains a great trait for identifying the best genotypes. Grain yield is the most complex trait in plants, and several attributes directly or indirectly influence it; thus, it can also be considered an index.

The coincidence index was calculated to determine the percentage of superior cultivars that the three strategies would select. Table 5 shows the results of these comparisons.

Table 5. Coincidence index based on the different selection intensities and comparisons of the univariate analysis (UNI), sum of ranks index (SR) and sum of standardized variables index (Z)

\begin{tabular}{llll}
\hline \multirow{2}{*}{ Selection intensities $(\%)$} & \multicolumn{3}{c}{ Coincidence index $(\%)$} \\
\cline { 2 - 4 } & UNI $\times$ SR & UNI $\times$ Z & SR $\times$ Z \\
\hline 5 & 0 & 0 & 100 \\
10 & 0 & 0 & 33.33 \\
15 & 60 & 40 & 80 \\
20 & 57.14 & 57.14 & 85.71 \\
25 & 62.5 & 75 & 75 \\
30 & 70 & 70 & 80 \\
\hline
\end{tabular}


The coincidence index between the strategies used to rank the cultivars corroborates the results obtained in the correlation analysis. For example, considering a 5\% selection intensity, using the SR compared with the $\mathrm{Z}$ index yielded $100 \%$ coincidence between the superior cultivars. Therefore, these indices efficiently classified the best cultivars.

When several environments are available, an alternative is to identify cultivars with greater adaptability and stability. In this case, Wricke's (1965) analysis was conducted, enabling identifying cultivars with greater agronomic stability, i.e., those contributing little to the interaction and responding positively to improved environmental factors (Table 6).

Table 6. Mean values of Wricke's (Wi) ecovalence and the Annicchiarico confidence index (Ii) for all cultivars

\begin{tabular}{|c|c|c|c|}
\hline \multirow{2}{*}{ Cultivars } & \multicolumn{3}{|c|}{ Total } \\
\hline & Grain Yiel* & Wi (\%) & Ii (\%) \\
\hline FPS Iguaçu & $34.90 \mathrm{e}$ & 5.16 & 66.14 \\
\hline NS 5106 IPRO & $45.21 \mathrm{~d}$ & 1.48 & 84.71 \\
\hline NS 5151 IPRO & $50.50 \mathrm{c}$ & 1.65 & 94.47 \\
\hline 95R51 & $45.96 \mathrm{~d}$ & 4.32 & 81.74 \\
\hline CD $250 \mathrm{RR}$ & $37.64 \mathrm{e}$ & 2.03 & 74.37 \\
\hline FPS Paranapanema RR & $44.24 \mathrm{~d}$ & 4.15 & 85.08 \\
\hline FPS Solimões RR & $44.95 \mathrm{~d}$ & 3.41 & 85.53 \\
\hline FPS Atlanta & $53.16 \mathrm{~b}$ & 1.38 & 99.07 \\
\hline RK 5813 RR & $54.25 \mathrm{~b}$ & 3.21 & 102.85 \\
\hline FPS Júpiter RR & $48.35 \mathrm{c}$ & 0.89 & 90.71 \\
\hline NS 5909 IPRO & $52.68 \mathrm{~b}$ & 2.81 & 98.98 \\
\hline NS 5959 IPRO & $53.74 \mathrm{~b}$ & 0.58 & 101.85 \\
\hline 5D $615 \mathrm{RR}$ & $48.32 \mathrm{c}$ & 1.69 & 91.67 \\
\hline FPS Urano RR & $45.82 \mathrm{~d}$ & 1.77 & 86.61 \\
\hline FPS Netuno RR & $58.23 \mathrm{a}$ & 0.55 & 109.83 \\
\hline FPS Solar IPRO & $54.97 \mathrm{~b}$ & 0.32 & 103.28 \\
\hline FPS Antares RR & $59.28 \mathrm{a}$ & 0.58 & 112.77 \\
\hline RK 6813 RR & $57.50 \mathrm{~b}$ & 1.12 & 109.90 \\
\hline 5D $690 \mathrm{RR}$ & $48.81 \mathrm{c}$ & 1.40 & 90.53 \\
\hline NS 6909 IPRO & $55.65 \mathrm{~b}$ & 2.59 & 106.42 \\
\hline NS 7000 IPRO & $64.88 \mathrm{a}$ & 4.93 & 121.20 \\
\hline CD $238 \mathrm{RR}$ & $59.29 \mathrm{a}$ & 2.11 & 112.12 \\
\hline M 7110 IPRO & $56.13 b$ & 3.13 & 105.36 \\
\hline TMG 716 RR & $45.80 \mathrm{~d}$ & 0.94 & 86.61 \\
\hline 97R21 & $56.64 \mathrm{~b}$ & 0.76 & 106.58 \\
\hline NS 7209 IPRO & $63.86 \mathrm{a}$ & 2.85 & 119.82 \\
\hline CG 68 RR & $61.49 \mathrm{a}$ & 2.55 & 115.42 \\
\hline NS 7300 IPRO & $61.79 \mathrm{a}$ & 3.14 & 116.18 \\
\hline NS 7338 IPRO & $59.62 \mathrm{a}$ & 3.92 & 111.53 \\
\hline CG 67 RR & $54.04 \mathrm{~b}$ & 0.51 & 101.68 \\
\hline CG 7464 RR & $61.10 \mathrm{a}$ & 3.06 & 112.60 \\
\hline CG 7665 RR & $58.50 \mathrm{a}$ & 4.87 & 108.33 \\
\hline 5G $770 \mathrm{RR}$ & $53.88 \mathrm{~b}$ & 7.25 & 99.63 \\
\hline CG 8166 RR & $58.98 \mathrm{a}$ & 5.30 & 109.36 \\
\hline $5 \mathrm{G} 830 \mathrm{RR}$ & $52.95 \mathrm{~b}$ & 13.59 & 97.03 \\
\hline Total & & 100.00 & - \\
\hline
\end{tabular}

Note. Averages followed by the same letter in the columns belong to the same group by the Scott-Knott test at $95 \%$ reliability.

Among the evaluated cultivars, 5G 830 RR contributed the most to interaction, accounting for $13.59 \%$ of the total variation. Cultivars SPF Jupiter RR, NS 5959 IPRO, SPF Neptune RR, Solar SPF RR, SPF Antares, TMG 716 RR 
97R21 and CG 67 RR contributed the least to the interaction, accounting for less than $1 \%$ of the total and were not always associated with good mean yields.

To identify cultivars with lower risks, the risk index was also analyzed. NS 7000 IPRO and NS 7209 IPRO showed the lowest risks, with confidence indices of 121.20 and 119.82, respectively. That is, at worst, these cultivars presented mean performances of $21.2 \%$ and $19.82 \%$ more than the overall environmental means, respectively (Table 6).

Researchers often study the absolute ripeness trait in soybeans. This attribute enables selecting cultivars with lower cycles. For adaptability/stability, studies should determine whether a change occurs in the magnitudes of these parameters when the cultivars are grouped according to the maturation group. Tables 7,8 and 9 present these results.

Table 7. Mean values of Wricke's ecovalence (Wi) and the Annicchiarico confidence index (Ii) for the maturation group (MG) I cultivars

\begin{tabular}{llll}
\hline \multirow{2}{*}{ Cultivars } & \multicolumn{3}{c}{ Group I } \\
\cline { 2 - 4 } & MG & Wi (\%) & Ii (\%) \\
\hline FPS Iguaçu & 5.0 & 15.25 & 73.17 \\
NS 5106 IPRO & 5.1 & 4.87 & 95.77 \\
NS 5151 IPRO & 5.1 & 2.27 & 106.56 \\
95R51 & 5.5 & 7.43 & 91.22 \\
CD 250 RR & 5.5 & 1.86 & 83.55 \\
FPS Paranapanema RR & 5.6 & 18.84 & 83.55 \\
FPS Solimões RR & 5.7 & 10.13 & 96.32 \\
FPS Atlanta & 5.8 & 14.21 & 112.46 \\
RK 5813 RR & 5.8 & 9.59 & 115.57 \\
FPS Júpiter RR & 5.9 & 6.30 & 103.02 \\
NS 5909 IPRO & 5.9 & 7.47 & 111.28 \\
NS 5959 IPRO & 5.9 & 1.77 & 115.39 \\
\hline Total & & 100.00 & - \\
\hline
\end{tabular}

Table 8. Mean values of Wricke's ecovalence (Wi) and the Annicchiarico confidence index (Ii) for the maturation group (MG) II cultivars

\begin{tabular}{llll}
\hline \multirow{2}{*}{ Cultivars } & \multicolumn{3}{c}{ Group II } \\
\cline { 2 - 4 } & MG & Wi (\%) & Ii (\%) \\
\hline 5D 615 RR & 6.1 & 8.24 & 88.36 \\
FPS Urano RR & 6.2 & 10.47 & 83.57 \\
FPS Netuno RR & 6.3 & 4.22 & 106.10 \\
FPS Solar IPRO & 6.3 & 2.76 & 99.83 \\
FPS Antares RR & 6.8 & 4.45 & 108.84 \\
RK 6813 RR & 6.8 & 3.90 & 105.84 \\
5D 690 RR & 6.9 & 11.42 & 87.54 \\
NS 6909 IPRO & 6.9 & 15.67 & 102.63 \\
NS 7000 IPRO & 7.0 & 38.85 & 117.28 \\
\hline Total & & 100.00 & - \\
\hline
\end{tabular}


Table 9. Mean values of Wricke's ecovalence (Wi) and the Annicchiarico confidence index (Ii) for the maturation group (MG) III cultivars.

\begin{tabular}{llll}
\hline \multirow{2}{*}{ Cultivars } & \multicolumn{3}{c}{ Group III } \\
\cline { 2 - 4 } & MG & Wi (\%) & Ii (\%) \\
\hline CD 238 RR & 7.1 & 3.57 & 104.54 \\
M 7110 IPRO & 7.1 & 12.05 & 99.05 \\
TMG 716 RR & 7.1 & 11.34 & 81.92 \\
97R21 & 7.2 & 2.79 & 99.68 \\
NS 7209 IPRO & 7.2 & 9.03 & 112.09 \\
CG 68 RR & 7.3 & 9.88 & 108.70 \\
NS 7300 IPRO & 7.3 & 1.97 & 108.11 \\
NS 7338 IPRO & 7.3 & 2.72 & 103.37 \\
CG 67 RR & 7.4 & 1.06 & 95.02 \\
CG 7464 RR & 7.4 & 7.41 & 105.33 \\
CG 7665 RR & 7.6 & 3.74 & 100.35 \\
5G 770 RR & 7.7 & 8.58 & 91.80 \\
CG 8166 RR & 7.7 & 4.21 & 101.27 \\
5G 830 RR & 8.3 & 21.62 & 88.75 \\
Total & & 100.00 & - \\
\hline
\end{tabular}

A change occurred in the magnitude of the components when the cultivars were separated by maturation group. For example, when analyzing all cultivars, the NS 7000 IPRO cultivar presented the lowest associated risk and a low contribution to the interaction (Table 6). In contrast, when evaluating only group II (Table 8) although this cultivar has a low associated risk, it yielded a high contribution to the $\mathrm{G} \times \mathrm{E}$ interaction.

\section{Discussion}

The environment also affected trait expression. In the present study, the progenies were evaluated in different locations and agricultural years. Under these conditions, influences from both predictable and unforeseeable environmental factors are expected (Allard \& Bradshaw, 1964).

The combination of environmental factors and cultivars was fundamental for the $G \times E$ interaction; thus, the cultivars likely did not present coincident performances in the different environments. Much of the interaction was due to the complex-type interaction (Table 2), which indicates that some cultivars stood out in specific environments, thus making recommendations difficult (Ramalho et al., 2012). These results corroborate reports in the literature (Gesteira et al., 2015; Silva et al., 2015; Soares et al., 2015), which described genotype-by-environment interactions for soybeans in Minas Gerais, Brazil.

The use of index selection in soybeans has been reported in the literature. Soares et al. (2015) adopted the sum of ranks index (SR) and found that it was efficient for selecting new soybean cultivars. Silva et al. (2016) used the sum of standardized variables index ( $Z$ index) and found that it efficiently identified productive cultivars with good seed quality, thus corroborating the results obtained in the present study.

No adaptability/stability studies exist in the literature in which the cultivars are compared by maturation group. However, Cavassim (2014) studied the effect of environments and used stability analysis methods to estimate the relative maturity of soybean cultivars and showed that this trait is strongly influenced by environmental factors depending on the method used to estimate the index.

\section{Conclusions}

Considering the univariate analysis (yield), the sum of ranks (SR) and the sum of standardized variables ( $\mathrm{Z}$ index), the NS 7000 IPRO and NS 7209 IPRO cultivars stand out.

The estimated adaptability/stability parameters differ when all cultivars are considered simultaneously compared with only considering maturity groups.

\section{Acknowledgements}

This work it was financed in part by the Coordenação de Aperfeiçoamento de Pessoal de Nível Superior-Brasil (CAPES) - Finnancial Code 001. This work was supported by the Conselho Nacional de Desenvolvimento Científico e Tecnológico- $\mathrm{CNPq}$ / MCTIC, through grant of productivity to the author Adriano Teodoro Bruzi. 


\section{References}

Allard, R. W., \& Bradsham, A. D. (1964). Implications of genotype-enviromental interactions in applied plant breeding. Crop Science, 4(5). https://doi.org/10.2135/cropsci1964.0011183X000400050021x

Annicchiarico, P. (1992). Cultivar adaptation and recommendation from alfafa trials in Northern Italy. Journal of Genetics and Breeding, 46, 269-278.

Brazil Ministry of Agriculture, Livestock and Supply. (2009). National secretariat of agricultural defense rules for seed analysis (1st ed., p. 398). Brasília, MAPA.

Cavassim, J. E. (2014). Classificação em grupos de maturidade relative para a soja comparando metodologias de estabilidade (Doctoral dissertation, Federal University of Paraná, Curitiba, Brazil).

Cruz, C. D. (2013). GENES-A software package for analysis in experimental statistics and quantitative genetics. Acta Scientiarum, 35(3), 271-276. https://doi.org/10.4025/actasciagron.v35i3.21251

Cruz, C. D., \& Castoldi, F. L. (1991). Decomposição da interação genótipos $\times$ ambiente sem partes simples e complexa. Revista Ceres, 38, 422-430.

Gesteira, G. S., Zambiazzi, E. V., Bruzi, A. T., Soares, I. O., Rezende, P. M. de, \& Silva, K. B. (2015). Seleção fenotípica de cultivares de soja precoce para a região Sul de Minas Gerais. Revista Agrogeoambiental, 7(3), 79-88. https://doi.org/10.18406/2316-1817v7n32015730

Hambiln, J., \& Zimmermann, M. J. de O. (1986). Breeding common bean for yield mixtures. Plant Breeding Reviews, 4, 245-272. https://doi.org/10.1002/9781118061015.ch8

Mendes, F. F., Ramalho, M. A. P., \& Abreu, Â. de F. B. (2009). Índice de seleção para escolha de populações segregantes do feijoeiro-comum. Pesquisa Agropecuária Brasileira, 44, 1312-1318.

Mulamba, N. N., \& Mock, J. J. (1978). Improvement of yield potential of Elo Blanco maize (Zea mays L.) population by breeding for plant traits. Journal of Genetics and Cytology, 7, 40-51.

R Core Team. (2016). R: A language and environment for statistical computing. Vienna: R Foundation for Statistical Computing. Retrieved from http://www.R-project.org

Ramalho, M. A. P., Santos, J. B., \& Zimmermann, M. J. O. (2012). Aplicações da genética quantitativa no melhoramento de plantas autógamas (p. 522). Lavras: Ed. UFLA.

Resende, M. D. V., \& Duarte, J. B. (2007). Precisão e controle de qualidade em experimentos de avaliação de cultivares. Pesquisa Agropecuária Tropical, 3(37), 182-194.

Scott, A. J., \& Knott, M. A. (1974). Cluster analysis method for grouping means in the analysis of variance. Biometrics, 31(4), 1019. https://doi.org/10.2307/2529204

Silva, K. B. (2016). Plasticidade fenotípica e análise de QTL para qualidade de sementes em soja (Doctoral dissertation, Federal University of Lavras, Lavras, Brazil).

Silva, K. B., Bruzi, A. T., Zuffo, A. M., Zambiazzi, E. V., Soares, I. O., Rezende, P. M. de, ... Coelho, M. A. de O. (2015). Adaptability and phenotypic stability of soybean cultivars for grain yield and oil content. Genetics and Molecular Research, 15(2). https://doi.org/10.4238/gmr.15026756

Soares, I. O., Rezende, P. M. de, Bruzi, A. T., Zambiazzi, E. V., Zuffo, A. M., Silva, K. B., \& Gwinner, R. (2015). Adaptability of soybean cultivars in different crop years. Genetics and Molecular Research, 4(3), 8995-9003. https://doi.org/10.4238/2015.August.7.8

Wricke, G. (1965). Zurberechning der okovalenzbei sommerweizen und hafer. Zeitschrift Fur Pflanzenzuchtung, $52,127-138$.

\section{Copyrights}

Copyright for this article is retained by the author(s), with first publication rights granted to the journal.

This is an open-access article distributed under the terms and conditions of the Creative Commons Attribution license (http://creativecommons.org/licenses/by/4.0/). 